\section{Stress tidlig i livet gir mer sykdom senere}

Det er sammenheng mellom psykososialt stress hos kvinnen $f \varnothing r$ fødselen og sårbarhet for sykdom hos barnet. Dette viser en svensk studie.

Det er velkjent at stress under graviditeten er uheldig for fosteret, men kan det påvirke helsetilstanden også senere i livet?

I en svensk kohortstudie svarte 209 gravide på spørsmål om psykososial belastning (1). Kortisolnivå ble målt $\mathrm{i}$ barnas hår $\mathrm{da} \mathrm{de}$ var i ettårsalderen. Barna til kvinnene med høyest psykososial belastning hadde høyest nivå av kortisol i håret. Ved ti års alder ble forekomsten av de 14 vanligste sykdommene registret hos barna. Da fant man at de samme barna også var oftere rammet av 12 av de 14 sykdommene som det ble undersøkt for. Én mulig forklaring kan være en dysregulering av hypothalamushypofyse-binyre-aksen.

- Sammenhengen mellom tidlig psykososial belastning og somatisk så vel som psykisk morbiditet og mortalitet i livsløpet er kjent, sier Indra Simhan, som er overlege ved Avdeling for barn og unges psykiske helse ved Sørlandet Sykehus i Kristiansand.

- Studien er interessant fordi man i den bruker kortisol i håret som markør for kronisk stress og registrerer prenatal psykososial belastning og fordi den omfatter barn $i$ et nordisk land. Funnene er i tråd med tidligere forskning. Det kan tenkes at større studiepopulasjon og bredere kartlegging av risikofaktorer også i spedbarnsperioden kunne ha styrket sammenhengene enda mer, sier hun. Studien bør stimulere til videre forskning også i Norge. Barneleger og barnepsykiatere bør samarbeide mer, mener Simhan.

\section{Martine Rostadmo}

Tidsskriftet

\footnotetext{
Litteratur

1. Karlén J, Ludvigsson J, Hedmark M et al. Early psychosocial exposures, hair cortisol levels, and disease risk. Pediatrics 2015; 135: e1450-7
}

\title{
Gir jerntilskudd økt risiko for malaria hos gravide?
}

\author{
Jerntilskudd til barn kan øke risikoen for malaria. Gravide kan imidlertid \\ trygt ta jern, viser en ny studie fra Tanzania.
}

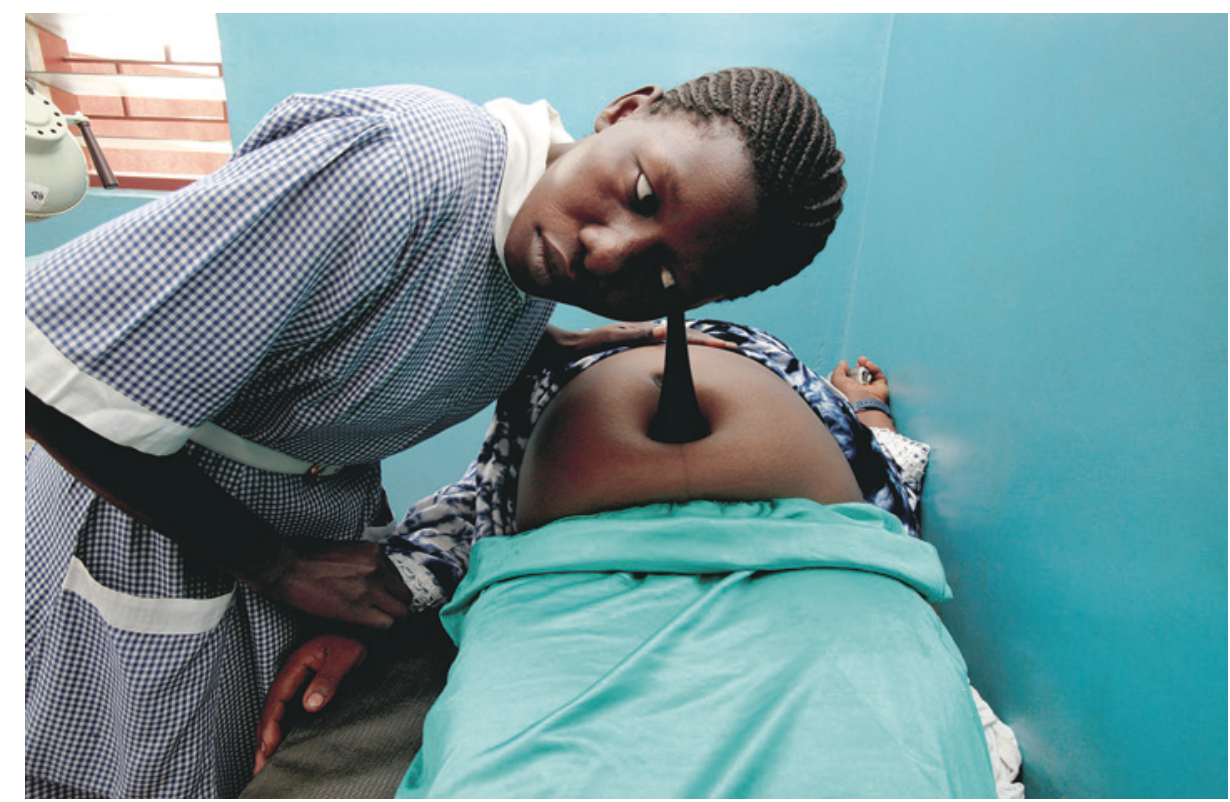

Illustrasjonsfoto: Science Photo Library

Anemi forekommer hos en firedel av jordens befolkning og er særlig vanlig hos kvinner og barn i Afrika sør for Sahara. Også i denne regionen er jernmangel den vanligste årsaken til anemi hos gravide. Jerntilskudd til barn kan gi økt risiko for malaria og andre perinatale infeksjoner, og det har vært usikkert om dette også kunne gjelde gravide. I en ny studie har man derfor sett på sikkerheten ved rutinemessig jerntilskudd til gravide i Tanzania (1).

Studien var dobbeltblindet og inkluderte 1500 hivnegative første- eller andregangsgravide uten alvorlig anemi (hemoglobinnivå $>8,5 \mathrm{~g} / 100 \mathrm{ml}$ som ble randomisert til å få $60 \mathrm{mg}$ jerntilskudd daglig eller placebo fra inklusjonstidspunktet lgjennomsnittlig 18,2 uker, senest svangerskapsuke 27) og frem til fødselen. Biopsi av placenta ble tatt for malariadiagnostikk med histopatologi og polymerasekjedereaksjon (PCR).

Jerntilskudd ga ikke økt risiko for placentær malaria (RR 1,03; $95 \% \mathrm{KI}$ 0,65-1,65). Fødselsvekten var heller ikke forskjellig i de to gruppene (3 $155 \mathrm{~g}$ mot $3137 \mathrm{~g}, \mathrm{p}=0,89$ ), men jerntilskudd hadde positiv effekt på maternelt hemoglobin- og ferritinnivå. Risikoen for anemi var signifikant redusert (RR0, 60; $95 \% \mathrm{KI} 0,51-0,71$ ), men for alvorlig anemi var risikoreduksjonen ikke signifikant (RR 0,68; $95 \% \mathrm{KI} 0,41-1,14$ ). Det var ingen statistisk signifikante forskjeller i utfall som dødfødsel, for tidlig fødsel, lav fødselsvekt eller neonatal $d ø d$.

Forfatterne konkluderer med at funnene gir støtte for å gi tilskudd av jern til gravide, også i malariaendemiske områder. Dette er i tråd med Verdens helseorganisasjons gjeldende anbefaling.

\section{Kristoffer Brodwall}

kristoffer.brodwall@gmail.com

Institutt for global helse og samfunnsmedisin Universitetet i Bergen

\section{Litteratur}

1. Etheredge AJ, Premji Z, Gunaratna NS et al. Iron supplementation in iron-replete and nonanemic pregnant women in Tanzania: a randomized clinical trial. JAMA Pediatr 2015. E-publisert 17.8. 